\title{
Study on Influence to Waste Water Treatment Plant's Sludge by Low- carbon Catalytic Combustion Furnace of Natural Gas
}

\author{
TianQi Ren ${ }^{1}$, Kai Fang ${ }^{1}$, Shihong Zhang ${ }^{1}$ \\ ${ }^{1}$ The University of Toledo, USA Department of Biological Engineering, Xiangxi National Vocational-Technical College,
}

Jishou, Hunan, China

\begin{abstract}
There are two parts in this experiment. One of is about the concentration of Variation of exhaust gas while heating sludge of waste water treatment plant. The other one is about introduce the problems of the traditional incineration processes of sludge of waste water treatment as compared between the sludge heated by natural gas catalytic combustion furnace and the tradition's. We can see that natural gas low-carbon catalytic combustion furnace realize the near-zero emission of contaminates
\end{abstract}

\section{Introduction}

Today, $90 \%$ of global industrial fuel derived from fossil fuels (oil, gas, coal), this situation will not change in the next 20 years[1]. There will be a huge emission of contamination by the traditional way of incineration.Energy is one of the most important issues of development of the national economy, and to accelerate the modernization.However the situation of quality energy supply and use are in poor in China. With the improvement of people's living standards, it is so urgent to reduce urban air pollution and to develop this highenergy gas, and extensive attention to how efficient use of the high-quality energy. Catalytic combustion burner as a new way to break the traditional flame flammable limit to achieve a lean methane / air mixture in the combustion of flammable limit, high combustion efficiency, improved energy efficiency[2].

A high quality clean energy, natural gas, with a low $\mathrm{C}$ / $\mathrm{H}$ ratio of high calorific value gas, has been used widely in city residents as fuel in Europe and other developed countries. Proven reserves and exploitation of natural gas increased year by year, and is developing rapidly[2].

Recently the majority burning mode of natural gas as an energy source is still combustion flame. However, there are some problems such the low rate of flame combustion energy utilization, pollution easy to be produced and others. While natural gas catalytic combustion burner as a new way, with the role of a catalyst in the combustion process, reduce ignition temperature of combustion, deepen its degree of oxidation and improve energy conversion efficiency of the fuel as suppressing the generation of NOx thermal effect by weakening the combustion peak and the combustion reaction was complete. And it can reach high combustion efficiency[3].

\section{Experimental set-up}

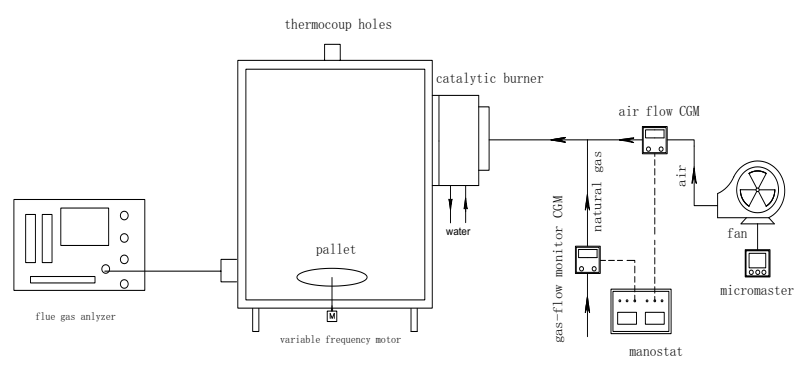

Fig. 1 Combustion system of catalytic combustion burner and flue gas analyzer

Fig. 1 presents the conventional diagram about system of catalytic combustion burner. The furnace body is connected to the catalytic burner, namely the catalytic combustion of burner. The catalytic combustion of burner installed two square catalytic honeycomb monolith every time .Every square honeycomb monoliths was $150 \mathrm{~mm}$ wide in sides of the square and $20 \mathrm{~mm}$ long, with squareshaped cells whose sectional area was $1 \mathrm{~mm} \times 1 \mathrm{~mm}$. The reaction region inside the catalysts was ended at about $10 \mathrm{~mm}$ from the monolith's entrance. The right part of burner connected with a section of pipe, which is a mixture of air and gas.

The control of air and gas respectively have their own independent reading device. The natural gas and air were regulated via GMS0050BRSN200000 natural gas meter and CMG400A080100000 air meter with $0 \sim 50 \mathrm{~L} / \mathrm{min}$ and $0 \sim 80 \mathrm{~m} 3 / \mathrm{h}$ of full-scale range respectively. The two 
meters were provided electric current. Exhaust gas went into the flue gas analyzer through hole on the left side of the burner. In order to improve radiant reflectance of the furnace cavity, high reflectivity of tin foil was taken in.

The natural gas was firstly let in (gas volume to $1 \mathrm{~L} / \mathrm{min}$ ), and the furnace starts running at the same time. After a few minutes, confirming the furnace is operating normally, the data were recorded every five minutes. The data were including temperature, concentration of carbon dioxide and carbon monoxide. Initially, the door of the heating Furnace was fully opened, in order to keep the temperature not too high. So when the temperature was relatively stable, the natural gas degree was adjusted into $5 \mathrm{~L} / \mathrm{min}$. The moment the temperature was relatively stable again, the door was shut gradually, so the temperature increased fifty or sixty degrees. The temperature was 366 degrees Celsius when the distance was $8 \mathrm{~cm}$ between door and doorjamb. The subsequent experiment process was the same taking the distance between door and doorjamb to $5,3 \mathrm{~cm}$, then the door was completely closed. And after the door's closing, the volumes of natural gas were adjusted into $6,7,8,9,10$ $\mathrm{L} / \mathrm{min}$, until the temperature rose to 800 degrees Celsius ,then heating pottery spent about 50 minutes until finishing.

For comparison with the heating potteries, the experiments of heating without potter inside catalytic combustion furnace of natural gas were also carried out. The main difference between the two was the impact of potteries' temperature, so the heating time was much less this time. And the data were recorded every five minutes as well, after combustion stabilized, the distance between door and doorjamb was turned into $8,5,3 \mathrm{~cm}$, and finally the door was shut down. After the door's closing, the volume of natural gas was changed into $6,7,8,9$, $10 \mathrm{~L} / \mathrm{min}$, until the temperature reached 800 degrees Celsius. Then the data were also calculated and analysed.

\section{Result and Discussion}

\subsection{Near-zero Pollutant Emissions of Catalytic Combustion Burner}

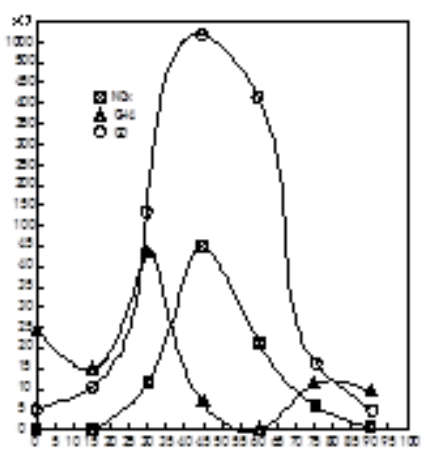

(a)

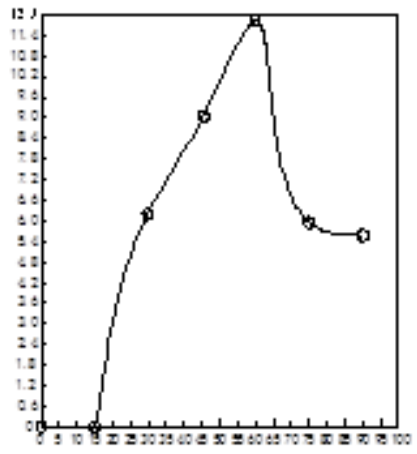

(b)

Fig. 2 The Variation of Exhaust Gas Constituent

Fig. 2 can be seen how each composition of emission gas changed and the whole variation trend of the content of emission gas while the experiment operating. In picture $a$, the first-15 minutes saw a decline in the number of $\mathrm{CH} 4$ first, and then the content of $\mathrm{CH} 4$ rose dramatically, reaching $43 \mathrm{ppm}$. But then it fell. The content of $\mathrm{CO}$ rose quickly, and it reached its highest point(1288PPM) at the 45th minute, and then the content of $\mathrm{CO}$ rapidly decreased which declare that the way natural gas reacting changed for catalytic combustion, so that natural gas nearly totally reacted. Besides, the content of NOx appeared in 15th minutes and rose quick, reaching it's highest point $44 \mathrm{ppm}$ after 30 minutes. And it decrease ,even reach $0 \mathrm{ppm}$, which must can be ignored. In addition, picture $b$, the content of $\mathrm{C} 02$, increasing continuously at first. After about 60 minutes the content of $\mathrm{C} 02$ drop dramatically,finally became steady which demonstrate that the reaction is almost stable.

In addition to our measured data, there is also a test report of composition and content of exhaust gas produced in catalytic combustion of natural gas provided by NIM, it can tell us that the contents of $\mathrm{CH} 4$ in exhaust gas was less than $10 \mathrm{ppm}$ and the emissions of $\mathrm{NO} 2$ and $\mathrm{CO}$ were also closed to zero. According to the result of composition and content of exhaust gas detecting by flue gas analyzer and NIM, it can be seen that there still produced a lot of $\mathrm{CO} 2$ when natural gas reacted. The smoke can be put into greenhouse, so that we can decrease the emission of $\mathrm{CO} 2$ while provide the $\mathrm{CO} 2$ for vegetation during the process of photosynthesis.

\subsection{Sludge of Waste Water Treatment Plant by Low-carbon Catalytic Combustion Furnace of Natural Gas}

The main words in all headings (even run-in headings) begin with a capital letter. Articles, conjunctions and prepositions are the only words which should begin with a lower case letter.With the improvement of people's living standards, people are increasingly in demand for water. And followed by, sewage produced also increased. There will be generate a lot of sludge in the waste water treatment processes, which accounts for about $0.3 \%$ to 
$0.5 \%$ of the treated water (with $97 \%$ moisture basis) [10]. According to statistics, in 2010 China produced a total of more than 30 million the amount of wet sludge $t$ (moisture content 80\%) [4]. As an inevitable by-product of waste water treatment sludge growing. Sludge contains large amounts of harmful toxic substances, such parasite eggs, pathogenic microorganisms, bacteria, synthetic organic compounds and heavy metals etc; useful substances such as plant nutrients (nitrogen, phosphorus and potassium), organic matter and water etc. Therefore, the sludge needs to treatment and disposal timely. That make sludge reduction, stabilization, harmless and utilization [10].Currently, there are methods for processing sludge, like landfill, composting, land use, incineration and pyrolysis [5] etc. Currently, because of sludge incineration technology has high degree of reduction and processing speed, small footprint, recycled energy for heating or electricity generation, etc. [6], is one of the most thorough ways to sludge reduction and harmless, which attracted widespread attention in domestic and international. Although incineration compared with other methods has it's own outstanding advantages, but it also not widely accepted by the domestic because of some shortcomings[8]. One of the problem is secondary pollution by sludge incineration flue gas. Sludge incineration will produce acid gases (SO2, HCl, HF, etc.), NOx, submicron dust, heavy metals and dioxins (PCDDs, PCDFs) etc. They will produce harmful substances to the environment and human beings. Domestic and international literature about emission types, generation mechanism and control technology of air pollutants from sludge incineration flue gas were reviewed by Fang Ping et al. [8]. The results and studies show that air pollutants of sludge incineration mainly include dust, heavy metals, dioxins and acid gas. It's also found that those can be control presently. In addition, there are some examples of domestic and foreign engineering analysis showed that as long as the use of appropriate flue gas treatment technology can completely control and prevent contamination of sludge incineration. The second problem is that the burning need to consume a lot of energy. What's more, the energy prices continue to rise and costs and operating costs of incineration are high [7]. Therefore, the development of high thermal efficiency of incineration has become a top priority.

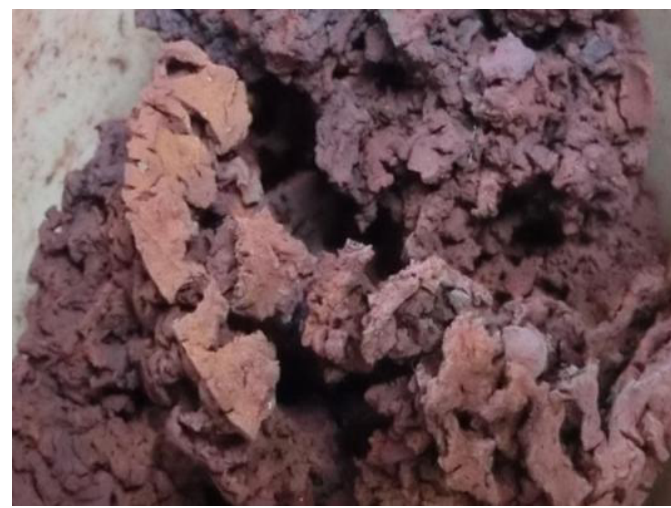

Fig. 3 The Part of Sludge Heated by Natural Gas Catalytic Combustion Furnace
Catalytic combustion means a flammable gas on the surface of the solid catalyst combustion. Catalytic combustion reaction is a heterogeneous catalytic reaction of complete oxidation (depth of oxidation). Different with partial oxidation reaction in the chemical industry applications (mild oxidation), catalytic combustion reaction let combustible gas molecules completely destroyed, and combustion products-carbon dioxide and water and release heat together[10].is the sludge which heated by natural gas catalytic combustion furnace, they have completely particles and no different with the traditional burning method. In addition, the lower activation energy of catalytic combustion reaction was allowed to take place under lean hydrocarbon concentrations. Thus the adiabatic reaction temperature below the limit NOx formation, and completely oxidized without forming $\mathrm{CO}$ and unburned hydrocarbons. Combustion takes place outside the limits of conventional vapor flammability, therefore combustion can burning more stable [9].

\section{Conclusions}

With the development of society, there are more and more demand for water. Along with sewage treatment, the number of sludge also increased. Catalytic combustion process can be used for sludge incineration one of the most effective methods of sludge reduction and harmless. Since the catalytic combustion can not only achieved near zero emissions, but also saving energies. Besides, it can reduce operating costs and conducive to environmental protection. In particular to reduce total emissions of carbon dioxide and nitrogen oxides, reducing the greenhouse effect and acid rain on the human environment harm. That we should continue to study.

\section{Acknowledgments}

The project was sponsored by the Beijing Municipality Key Lab of Heating, Gas Supply, Ventilating and Air Conditioning Engineering; 2015 Funding Project (Building Environment and Facilities Engineering, Water supply and Sewerage engineering), the Core Course of Heat Transfer and Fine Quality Course of Thermodynamics.

\section{References}

1. X Kong. Developmental Direction of Energy Saving For Industrial Furnace In The New Century, 2003.9.

2. Zhang Jie, Zhang Shihong.Journal of Beijing University of Civil Engineering and Architecture. 2008(24).

3. Prasad R,Kennedy L A,Ruckenstein E. Catalytic com-bustion of methane in matalytic honeycomb monolith burners[J]. International Journal of Energy Research,2000(24):1181-1201].

4. People's Republic of China Ministry of Housing and Urban. About the national urban sewage treatment 
facilities in the fourth quarter of 2010 the construction and operation of communications [R]. Built city[2011]NO.12,2011,1,28.

5. Wan Li-guo, Tian Yu, Zhang Li-jun, etal. Status and progress on high temperature pyrolysis of sewage sludge[J].Environmental Science\& Technology, 2011, 34 (6):109-114.

6. Wu Hong-xiang,Zhao Zeng-li,Li Hai-bin,et al. Cocombustion of sewage sludge, coal and sawdust[J]. Environmental Science\&Technology 2011, 34(7): 73-77.

7. Li Jun, Wang Zhongmin, Zhang Ning, Yang Xiaodong Song, Weihua, Chen Gang.Study of Sludge Incineration Technology. Environmental Engineering, 2005(6).

8. Fang Ping, Cen Chao-ping, Tang Zi-jun, Tang Zhixiong. Air pollutants emission and their control from sludge incineration: a review $[\mathrm{J}]$. Environmental Science \& Technology, 2012, 35(10): 70-80.[10]. Fu Zhongcheng, Cedel Xue, Li Zhenming new gas combustion device [M] Beijing: China Building Industry Press, 1984: 171-190.

9. Zhang Shihong, Dupont V [France], Zhou Qi, et al. natural gas catalytic combustion of near-zero emission mechanism and application [M] Beijing: Science Press, 2008: 1-1.

10. Zhang Zijie editor. Drainage works next book. 4th edition. Beijing: China Building Industry Press, 1999. 